\title{
John Goodwin's Cretensis: A Response to Gangraena
}

\section{Araz Mohammed Ismail}

English Department, College of Education, University of Raparin,Rania, Kurdistan Region, Iraq Email: Araz.ismail@uor.edu.krd

\begin{abstract}
:
Seventeenth-century scholars such as Jesse Lander have lately argued that if there was one thing to be revolutionized by the political disturbance in the early decades of the century, it was reading. The political instability caused by the battle between the king and the Parliament undeniably, and effectively influenced people's lives, but people were also indirectly and intellectually experiencing those occurrences through reading about them (Anderson and Sauer 217). Jesse Lander also notes a "consequential intersection between religious controversy and print technology in early modern England" (1). Printed polemical exchange then becomes one of the most distinctive features of the era, as instantiated by the puritan Thomas Edwards's 1646 Gangraena and the immediate responses it attracted. This paper investigates the publishing, and reading culture of seventeen century Britain by examining how the independent John Goodwin-Edwards's Cretensis responds to Gangraena, contextually analyzing some of the strategies he applies, while at the same time probing the immediate context. The paper concludes with a brief account stating how the response in question helps illuminating the nature of polemical print controversy in early modern England.
\end{abstract}

Key words: Gangraena, Cretensis, printing culture, Edwards, Goodwin 
Following the termination of state procedures to impose printing regulations in 1641, the number of printed books and pamphlets hugely increased, and this served to entail a stately-controlled reading material available for citizens. The English Church was similarly worried that freedom to publish books about religious topics would inevitably lead to heresy and schism. Both the state and the Church fulfilled their attempts to introduce limitations to the available reading material through prepublication licensing orders, by which "authors, printers, and publishers were obliged" to produce before an official licenser a manuscript of their would-be-printed texts (Anderson and Sauer 217-8). Anonymous publication was considered an "offense, and "unlicensed printing was a straightforward criminal act" (Anderson and Sauer 223). Perhaps this explains why Goodwin wanted to have on the title page of his Cretensis boldly written: "Published according to Order". This statement does not only allow Goodwin to confirm his conformity with the orders, but also to publish himself as "a well-willer to the Saints, in the work and patience of Jesus Christ" (italics added). As a strategy, this enables him both to defend himself against the Presbyterian Edwards and also helps publicize Cretensis. Provided that "the usual method of advertising early modern printed works to potential readers was displaying the title page" (Anderson and Sauer 220), Goodwin can be said to have very strategically and effectively designed the cover page of Cretensis with his printer Mathew Simmons. Being able to convince the London readers that his work -officially authorized by the church and state licensers-was not an offense to religion, Goodwin could presumably win both the Independent and the Presbyterian readers. As Hughes underlines, early modern readers did not take for granted the character and status of a book, and there was "nothing inherently trustful or trustworthy about a book" (56). Rhetorical and technical strategies thus had to be adopted by authors, printers, and booksellers "in order to convince" (56). This is exactly what Goodwin does in Cretensis- a fifty page pamphlet in the form of Quarto, making a handy, cheap book, at a time when people could not afford buying many pamphlets.

Edwards's Gangraena is a "Catalogue and Discovery of Many of the Errors, Heresies, Blasphemies and Pernicious Practices of the Sectaries", and Goodwin's aim is to set out a religious mission to "cure" and "prevent the spreading" of that "dangerous ulcer", Gangraena (John Goodwin).With regard to the 180 errors that Edwards has accused the Sectaries and the Independents of, Goodwin argues that he "will discover and find out" more errors and heresies among the Presbyterians (3). Just as Edwards accuses the Independents and the Sectaries of heresies and errors, Goodwin accuses him back with a "greater" sin: reporting the Saints' infirmities for Satan. Even if Edwards's charges "were true", Goodwin believes that "they that scattered them were more innocent than he that gathered them up", particularly with the "intention to call the world to see the nakedness of the Saints" (4). He quotes from Bible that "the sin of Cham in discovering the nakedness of his Father unto his Brethren was greater than the sin of his Father in being drunk" (Goodwin 4). This way Goodwin both reduces the intensity of the charges against himself and his party by showing that to err is human nature, and also charges Edwards for being "Satan's counsel" (1). He further tries to defy the Christ-like figure Edwards endeavours to create for himself throughout Gangraena. He 
illustrates many dissimilarities between Edwards and Christ, explaining that Edwards's lack of tolerance, his secret agents, and his desire to report the Saints' nakedness and wickedness prevent him from being a Christ-like person, and thus he "shall suffer, not as a Christian, no with Christ, but as a malefactor and male doer" (Goodwin 18-9). This is simultaneously accompanied by an insistence that he himself-Goodwin- is the opposite of Edwards, which means he resembles Christ.

Goodwin also calls into question Edwards's credibility to debate and his ability to establish logical arguments, and in so doing he tries to convince Edwards's Presbyterian readers -whom he thinks have already welcomed his writings without much consideration- to doubt his trustworthiness. Hughes highlights that it was important to the early seventeenth-century readers to be told that their ministers were susceptible to mistakes "so that they would not fall into a lamentable slavery" (252). Goodwin underscores Edwards's weak Latin and his vague grammar and accuses him of not understanding Latin and of misusing Calvin's quotations. Edwards's misinterpretation of Latin, in the words of Goodwin, prove him to "be a very illiterate man, and not able to construct a piece of plain Latin" (24). He further makes "an experiment upon Mr Edwards " by offering him few of Calvin's quotations to see if he is able to translate them into English or not, and judges him to be "incapable of the English sense of a Latin sentence" (24). Edwards's supposed inability to understand Calvin does not only weaken his place in the religious debate by debilitating his credibility, but also puts him in tension with Calvin. For Goodwin argues that it was Calvin's enemies who misconstrued him and "put Calvin's head and hands at odds" (Tai Liu, ODNB).

This multi-layered attack aimed at disgracing Edwards among his readers is further extended to the many unnamed letters included in Ganraena of which Goodwin believes none to be true. If Edwards considers himself the commander in chief in the Presbyterian wars against the Sectaries and Independents, and if the stories told in the letters are not his own creations, then he has "no reason to hide the name of his Captains" and those who do him service (7). For Goodwin, the sole reason why Edwards does not name those who have sent him letters is that Presbyterians "without any demurre or consideration at all, believe all that is contained in the letters from the first to the last of them" (7). He continues to say that "the zeal of High Presbytery, hath eaten him up, and not left him so much for himself ", referring to Edwards (19). Henceforth, not only Edwards is discredited by this attack, but also the entire Presbyterian party is judged to be naive and unquestioning. That Goodwin's target is not only the person of Edwards but the whole Presbyterian party is underpinned by Hughes' argument that in the debates of 1640s it was considered that truth was like a "chain of unbreakable links so that if one element could be challenged, the whole construction was worthless" (266). In this sense, when Goodwin obsessively details on Edwards's mistakes in Gangraena he does not simply attack him but also his party. If he can prove Edwards wrong, even at one point, that might suffice to reject Gangraena's accusation that all the existing different sects, beliefs and heresies destroy the fabric of the national Church and also the structure of the body politic. Proving Edwards wrong is an important manoeuvre that proves this otherwise; that it is not the Independents but the Presbyterians who are the real danger to 
the nation. Goodwin's metaphor of the chariot well testifies that he uses Edwards to attack Presbyterianism when he writes: "if his chariots and horsemen fail, surely his [infantry] will [yield] the field" 41". In a sense, if the high minister of the Presbyterians is wrong -Edwards- why not the whole party?

John Coffey states that Goodwin was "the number one target" of Edwards's Gangraena, and he was seen the most formidable enemy to Presbyterianism- a godly associate who had "strayed from the true path" (2). The fact is that Goodwin was "too independent to subscribe to any particular ideological 'ism' " (Tai Liu, ODNB). Goodwin was among the Independent ministers who held to the belief that God alone had power over conscience, and that the "individual believer should search the Scripture and think for himself" (Coffey 118). Independents also believed that people should voluntarily consent and submit to any church, and they should also be allowed to depart from it once they feel they do not have peace walking with that church. Independency then was the kind of church government that refused "compulsion and imposition" (118). This was in strong opposition to Edwards's Presbyterian stance that called for a "reformed, coercive, national church with hostility to political and religious radicalism" (Hughes 18). It is on this basis that Edwards calls for the eradication of the disparate sects and groups, and Goodwin defends their freedom.

Another strategy of attack in Cretensis by which, seemingly, Goodwin tries to clinch his argument against Edwards is to say that not only Presbyterians are wrong, but also Edwards himself is a bad Presbyterian. Hence, he is a man who is not cultivated enough to understand and respect the very principles of his political, religious institution; a man who in defending his party damages it and in attacking his enemies elevates them. Which is why, the course Edwards has taken to defame the "innocent Independents" and to "drown them into the Black Sea of infamy" has more likely carried them to the "Faire Havens of honour" (Goodwin 2). In Ganreana, Edwards spends a good deal charging the Independents with playing cards and going bowling -things that he considers heretical, but Goodwin finds in them no transgression of any law. Paradoxically though, in Cretensis these charges become a heavier burden on Edwards himself than on the Independents when Goodwin names a number of Presbyterian ministers from Edwards's church who were involved with him in the "innocent transgression" of bowling (32-3). Edwards then has accused his friends of something which is prohibited by neither Godly nor earthly laws (32). Thus, in Goodwin's metaphor Edwards becomes "an evil bird that defies his own nest" (33).

This strategy whereby Goodwin tries to dissociate Edwards from his Presbyterian party allows him both to defend himself against the charges laid against him and to put Edwards in a difficult condition. Because Edwards has already offended his friends with false accusations he cannot expect support from them, and this may even affect his credibility amongst his party and people. Goodwin does not stop there, but further suggests that even if he were a Presbyterian he would not trust Edwards's accounts regarding many topics, especially the number of the Sectaries' meetings in the city of London (49). Edwards has claimed that at least eleven meetings are held by the Sectaries in 
one parish of London, but Goodwin says that he cannot even prove half of the number suggested. He also asserts that with that "loud untruth" Edwards has abused "the honourable Houses of Parliament" (49). This is yet part of the scheme that works to drive Edwards into tension with his supporters. As if he were a true defender of the Presbyterian party, Goodwin suggests to them to seek ways to "heal the Ganrene of his pen, and to refrain the further spreading of it: otherwise their Names and Reputations are but so many dead corpses" (34). As the title page suggests the aim of Cretensis is to suggest "the best means" for the cure of the perilous Gangraena, and Goodwin can consider him winner if one of the means be the Presbyterians themselves.

Effectively, throughout Cretensis Goodwin feminizes Gangraena; instead referring to the book as it, Goodwin refers to it as she or miss Gangraena. Stevie Davies observes that Edwards's Gangraena was "propaganda to vilify the sexual mores of the radical sect" (97). This said, Goodwin's feminization of Gangraena then turns the book into a vulnerable woman "in the face of a society which requires [it] to be silent in the public sphere" and marks it as "whore" if it speaks "out of turn or make exhibitions" of itself ( Davies 104). This attack culminates only when Goodwin conspicuously calls Gangranea a "great whore, which corrupts the Earth with her fornication" (50). Seeing the book as a whore, "the woman who did not confine her sexual activities to her husband" (Koehler 80), can be seen a manoeuvre to charge the book with incontinency. A whore's "sexuality, which lacked a condition of emotional dependency on one man and was not centred around the institutional family, was illegitimate, as were the children arising from her liaisons" (Koehler 80). Just as a whore is unable to control her sexual passion, Gangraena then cannot control what it is saying. Thus Goodwin turns the book into some kind of verbose woman that cannot control what she is saying and, as a result, what she is uttering is just ridiculous and nonsense.

\section{Conclusion:}

A critical, contextual analysis of Cretensis assists a better conception of the nature of the seventeenth-century printed polemical exchange in England, in terms of the language used by polemicists, and the political and religious background that shaped it. As the country experienced unprecedented religious and political upheavals, polemical writers fought each other in their print publications. Therefore, the debates took on a religious nature. While polemicists like Edwards considered their pens instruments of the Presbyterian cause, Goodwin inclined to the Independent party, at least at some stage in his life. In terms of the language used in the religious debates, Cretensis shows that polemical writings were often filled with metaphors, backed up by quoting other writers and books. The reason for that, as Hughes has underlined, might have been because there was tendency to direct books at a "middling readership as well as an educated elite" (Goodwin 223). It also tells us that the debates were not only dependent on being a learned man in English, but also on expressing an ability to master other languages, especially 
Latin. This is why Goodwin's vitriolic criticism on Edwards centres on his incapability to comprehend and correctly use Latin. Moreover, "extensive quotation and counter-quotation" was another feature of the polemical exchanges (Hughes 264). Hardly do you turn over a page in Cretensis without quotations, sometimes from the author's own books. Nonetheless, the language sometimes could be very virulent; Goodwin's references to Gangraena and its author as "defamatory untruths", "Dragon-like spirit", "naked of principles, speaking shamelessly", " a letter full of follies", "shameless untruths", and "great whore" testify this idea (Goodwin 9, 19, 35, 45, 49, 50). Thus, unlike nowadays, an impolite language could be used to debate about religious matters. In addition, Goodwin's choices of his printer and bookseller also tell us something about the politics of the polemics; Cretensis is printed by Mathew Simmons for Henry Overton. Amos Tubb discusses the politics surrounding print publications and notes that pamphleteering did not only divide polemicists but also publishers and booksellers according to their political ideologies (289). This explains why Mathew Simmons was Goodwin's printer; both of them shared similar interests in matters of religious reform endorsed by the army (Tubb 296). The fact that in his arguments against Edwards, Goodwin often refers to other Independent writers tells us that the exchanges were carried out collectively in the sense that groups of writers in the same political or religious party consulted each other and shared each other's idea. This is why Goodwin finds it appropriate to clear some accounts with his rival on "behalfe of others" (38).

\section{Works Cited:}

Anderson, Jennifer, Elizabeth Sauer (ed). Books and Readers in Early Modern England: Material Studies. Pennsylvania: University of Pennsylvania, 2002. Print.

Coffey, John. John Goodwin and the Puritan Revolution: Religion and the Intellectual Change in Seventeenth Century England. Woodbridge: The Boydell Press, 2006. Print.

Davies, Stevie. Unbridled Spirits: Women of the English Revolution: 1640-1660.London: The Women's Press Ltd, 1998. Print.

Goodwin, John. Cretensis: Or A Brief Answer to an Ulcerous Treatise. London: 1646. Web. 20 Jan 2018. available at EEBO.

Hughes, Ann. Gangraena and the Struggle for English Revolution. New York: Oxford University Press, 2004. Print. 
Koehler, Lyle. A Search for Power: The Weaker Sex in Seventeenth Century New England.

London: University of Illinois Press, 1944. Print.

Lander, Jesse M. Inventing Polemic: Religion, Print, and Literacy Culture in Early Modern

England. Cambridge: Cambridge University Press, 2006. Print.

Tai Liu, 'Goodwin, John (c.1594-1665)', Oxford Dictionary of National Biography, Oxford University Press, 2004; online edn, Jan 2008. Web. 01 Feb 2018. doi:10.1093/ref:odnb/10994

Tubb, Amos. "Independent Presses: The Politics of Print in England During the Late 1640s". The Seventeenth Century Vol. 27, No 23 (2010): 287-312. Web. 01 Fed 2018.

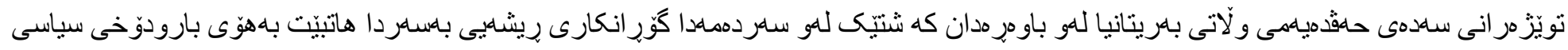

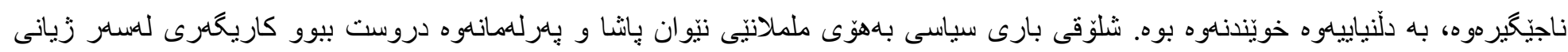

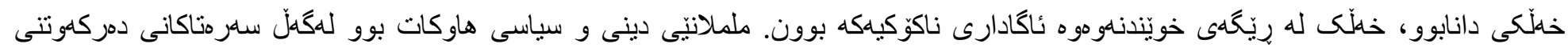

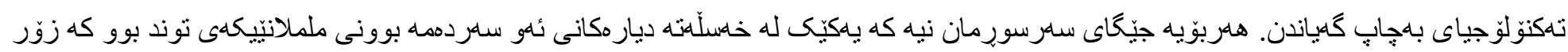

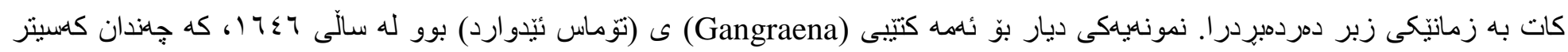

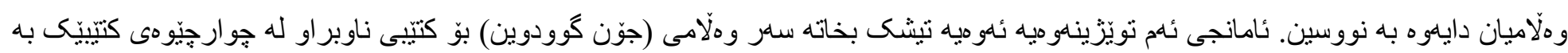

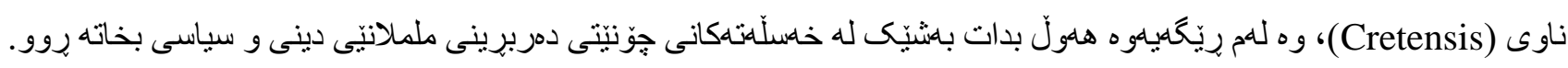

